\title{
At the Brink of Federation
}

The dues structure proposed by Copes and endorsed by Council at Midwinter represents the first step toward a federated American Library Association. The dues structure provides for a basic personal membership of $\$ 35$ plus the option of joining divisions at a cost of $\$ 15$ for each division selected. The new dues schedule should produce several short-range impacts. Many librarians who are not now members of ALA should be willing to join or rejoin the association. The $\$ 15$ division charge will discourage some members from participating in divisional activities. It could also signal the end of one or more ALA divisional journals. CRL and the CRL News will be placed in a precarious financial position. The division could no longer offer its two publications to nonmembers at the current rate of $\$ 15$ without reducing the incentive for belonging to ACRL itself. An increase in the journal subscription will produce a further reduction in nonmember subscription income. Also, if divisional membership declines initially, which is not an unreasonable assumption, the burden on ACRL's budget to support its publications will increase. It is estimated that approximately $\$ 25,000$ $\$ 30,000$ from membership dues will be needed to finance the journals assuming that the expenditures remain at approximately the same level. If the ACRL personal membership were to decline to the 8,000 level, the total revenue available to division activities, once publication costs are subtracted, would amount to $\$ 70,000$. Obviously ACRL cannot hope to develop vigorous programs of activities at this budgetary level. The solution to the problem is more members.

Academic librarians have grumbled over the current status of ACRL within ALA for many years. It has always been my conviction that it would be a mistake if ACRL completely severed its relations with ALA. Today professional librarians must speak out on national issues such as legislation, intellectual freedom, and international librarianship as one voice. A series of fragmented, independent librarians, such as those in academia, law, music, school, and public groups, will not be able to generate clout at the national level.

The immediate challenge to ACRL is to develop program activities which can be offered to academic librarians at the regional and the state levels. ACRL must become more active at state and regional meetings. ACRL must also promote a vigorous campaign to recruit new members. The recent success of the AASL should serve as an incentive to ACRL and other divisions.

The proposed dues structure represents both risks and benefits. To succeed, ALA must increase its membership, but the proposal offers some of the operational flexibility that many of us have desired. As a personal member of ACRL, I recommend a yes vote on the dues proposal.

RICHARD M. DOUGHERTY 